(4) LA -8943

(1)

DR QU

I- 1186

Los Alamo National Laboratory is operated by the University of California for the United States Department of Energy under contract W-7405-ENG-36.

A Review of Operating Experience at the Los Alamo Plutonium Electrorefining Facility, 1963-1977 LOS AIJIñOSS LosAlamos National Laboratory 


\section{DISCLAIMER}

This report was prepared as an account of work sponsored by an agency of the United States Government. Neither the United States Government nor any agency Thereof, nor any of their employees, makes any warranty, express or implied, or assumes any legal liability or responsibility for the accuracy, completeness, or usefulness of any information, apparatus, product, or process disclosed, or represents that its use would not infringe privately owned rights. Reference herein to any specific commercial product, process, or service by trade name, trademark, manufacturer, or otherwise does not necessarily constitute or imply its endorsement, recommendation, or favoring by the United States Government or any agency thereof. The views and opinions of authors expressed herein do not necessarily state or reflect those of the United States Government or any agency thereof. 


\section{DISCLAIMER}

Portions of this document may be illegible in electronic image products. Images are produced from the best available original document. 
Edited by Jill Warren

Photocomposition by Alice Creek

\section{DISCLAIMER}

This report was prepared as an account of work sponsored by an agency of the United States Government. Neither the United States Government nor any agency thereof, nor any of their employees, makes any warranty, express or implied, or assumes any legal liability or responsibility for the accuracy, completeness, or usefulness of any information, apparatus, product, or process disclosed, or represents that its use would not infringe privately owned rights. References herein to any specific commercial product, process, or service by trade name, trademark, manufacturer, or otherwise, does not necessarily constitute or imply its endorsement, recommendation, or favoring by the United States Government or any agency thereof. The views and opinions of authors expressed herein do not necessarily state or reflect those of the United States Government or any agency thereof. 
UC-25

Issued: December 1981

\title{
A Review of Operating Experience at the Los Alamos Plutonium Electrorefining Facility, 1963-1977
}

\author{
L. J. Mullins \\ A. N. Morgan
}

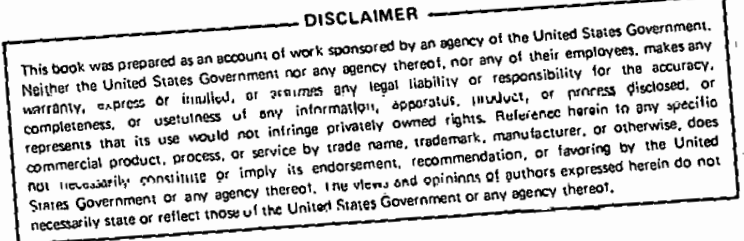




\section{PAGES ii to iii WERE INTENTIONALLY LEFT BLANK}




\section{CONTENTS}

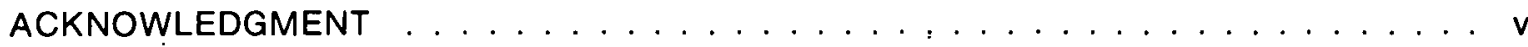

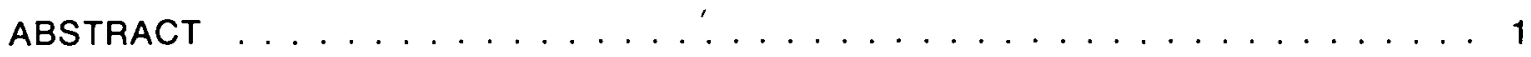

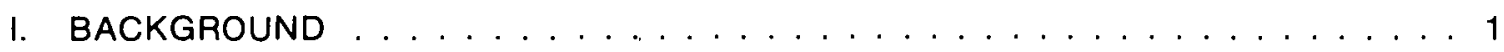

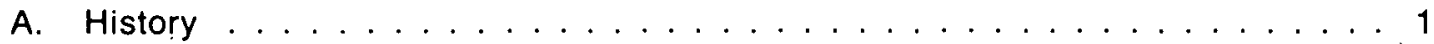

B. Why Electrorefine? . . . . . . . . . . . . . . 1

C. Plutonium Electrorefining, Principles of Operation $\ldots \ldots \ldots \ldots \ldots$

D. Electrorefining Cell Components . . . . . . . . . . . . . . 3

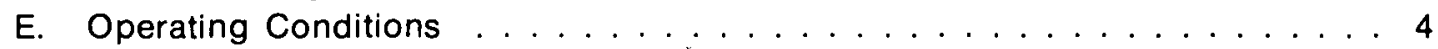

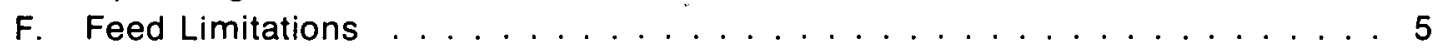

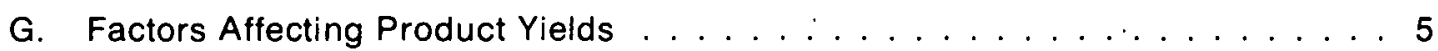

II. DESCRIPTION OF THE LOS ALAMOS ELECTROREFINING OPERATION . . . . . 6

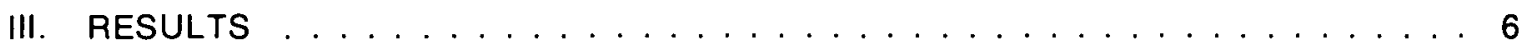

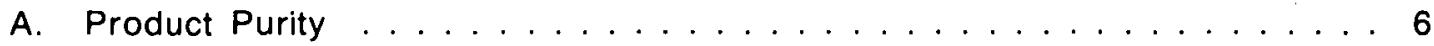
B. Plutonium Material Balances . . . . . . . . . . . . . . 7
C. Product Yields and Plutonium Utilization . . . . . . . . . . . . . 8
D. Anode Depletion, Collection Efficiency, and Process Efficiency . . . . . . . 10

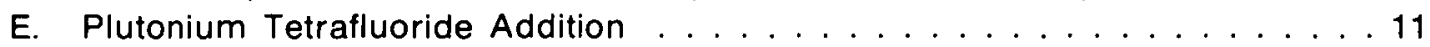

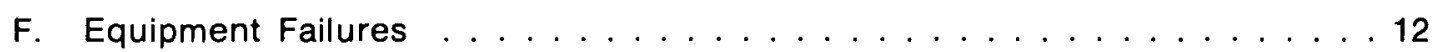

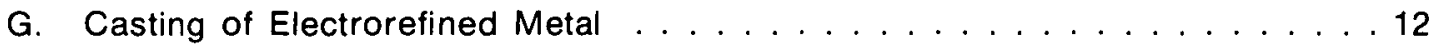

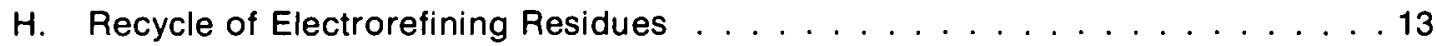

IV. SUMMARY AND RECOMMENDATIONS $\ldots \ldots \ldots \ldots \ldots \ldots \ldots$

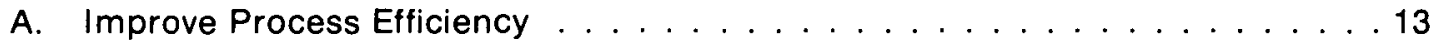

B. Improve Operational Efficiency . . . . . . . . . . . . . . 13

C. Nonaqueous Recycle of Process Residues . . . . . . . . . . . . . . 14

D. Summary . . . . . . . . . . . . . . . . . . . . . . . . 14

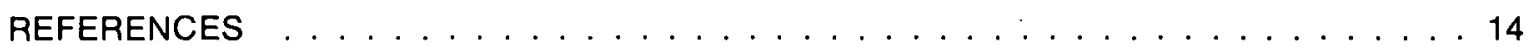

APPENDIX OPERATING PROCEDURES FOR ELECTROREFINING

PLUTONIUM METAL . . . . . . . . . . . . . . . . . . 16 
LA --8943

DE8 2010022

\section{ACKNOWLEDGMENT}

We thank technicians C. E. Rendell, B. R. Babcock, C. A. Emery, C. Arnold, C. Stevens, L. E. Post, and S. A. Apgar for their successful operation of the Los Alamos Electrorefining Facility over the years. 


\title{
A REVIEW OF OPERATING EXPERIENCE AT THE LOS ALAMOS PLUTONIUM ELECTROREFINING FACILITY, 1963-1977
}

by

\author{
L. J. Mullins and A. N. Morgan
}

\begin{abstract}
This report reviews the operation of the Los Alamos Plutonium Electrorefining Plant at Technical Area 21 for the period 1964 through 1977. During that period, approximately $1568 \mathrm{~kg}$ of plutonium metal, $>99.95 \%$ pure, was produced in 653 runs from $1930 \mathrm{~kg}$ of metal fabrication scrap, $99 \%$ pure. General considerations of the electrorefining process and facility operation and recommendations for further improvement of the process are discussed.
\end{abstract}

\section{BACKGROUND}

\section{A. History}

Plutonium electrorefining procedures developed at the Los Alamos National Laboratory in the early $1960 \mathrm{~s}^{1-12}$ resulted in the construction in 1963 of an electrorefining plant ${ }^{5}$ operated at Technical Area (TA)-21 from 1964 through 1977. In 1978, the electrorefining line was moved from TA-21 to the new Los Alamos Plutonium Facility at TA-55. This report reviews the operating experience gained during the 14 years of operation at TA-21.

\section{B. Why Electrorefine?}

Electrorefining is a very attractive operation for applications in which the feed materials are impure metals or alloys and the desired product is pure metal. In this process, impure metal is dissolved at the anode and pure metal is deposited at the cathode. This simple electrolytic conversion of impure-to-pure metal eliminates the many processing steps in plutonium recovery through chemical processing. In addition, electrorefined metal is purer than that produced by chemical conversion of compounds to metal.

Electrorefining has been used extensively for commercial purification of metals in aqueous solutions. For example, many major refineries use aqueous electrolytes for purifying copper, nickel, cobalt, lead, tin, silver and gold. ${ }^{13}$ Active metals, such as alkalis, alkaline earths, lathanides, and actinides, however, cannot be deposited in aqueous solution. These metals require molten salt electrolytes. Molten salt electrorefining processes have been studied extensively for aluminum, lead, plutonium, beryllium, niobium, titanium, vanadium, zirconium, tungsten, molybdenum, uranium, tin, and antimony. ${ }^{14}$ In spite of these numerous studies and the potential advantages of electrorefining, aluminum refining is the only process that has found extensive industrial use. ${ }^{14}$ Molten salt electrorefining, however, is an ideal processing tool for active metals that have reasonably low melting points, such as aluminum $\left(660^{\circ} \mathrm{C}\right)$, plutonium $\left(640^{\circ} \mathrm{C}\right)$, and neptunium $\left(637^{\circ} \mathrm{C}\right)$. 


\section{Plutonium Electrorefining, Principles of Opera- tion}

In the Los Alamos refining cell (Fig. 1), the magnesia crucible consists of two concentric cylindrical containers. The inner cup contains the impure molten plutonium anode and the outer cup contains the electrolyte. During operation, plutonium is oxidized at the anode and reduced back to metal at the cathode. Therefore, the height of metal in the anode decreases during a run as the height of the product ring or doughnut increases. The cell reactions are simply

$$
\begin{aligned}
& \text { Anode }-\mathrm{Pu} \text { (impure) } \rightarrow \mathrm{Pu}^{+3}+3 \mathrm{e}^{-} \\
& \text {Cathode }-\mathrm{Pu}^{+3}+3 \mathrm{e}^{3} \rightarrow \mathrm{Pu} \text { (pure) }
\end{aligned}
$$

Therefore, the net cell reaction is

$$
\mathrm{Pu} \text { (impure) } \rightarrow \mathrm{Pu} \text { (pure) }
$$

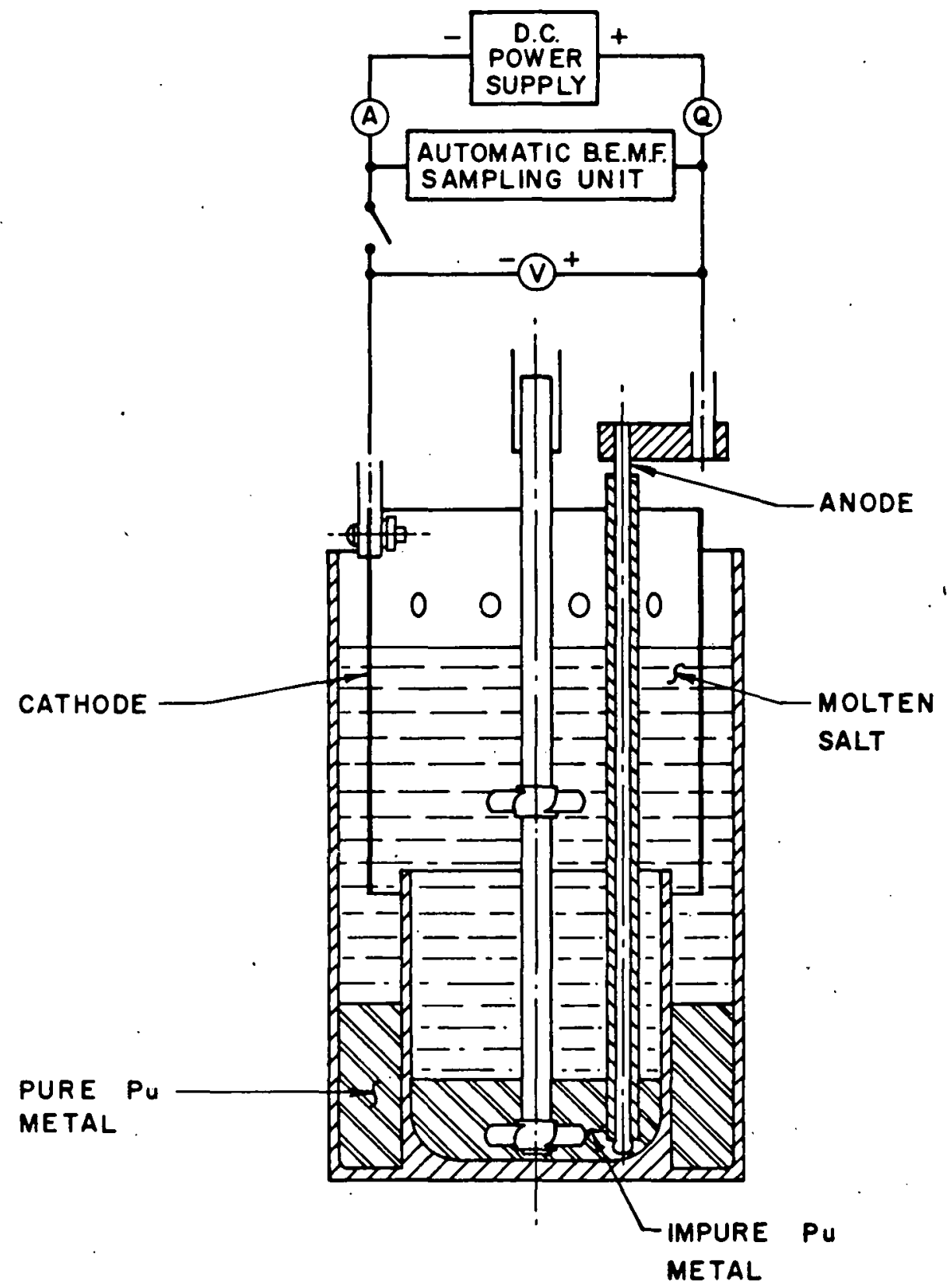

Fig. 1. Los Alamos electrorefining cell. 
Because plutonium is a very active or electropositive metal, most of the impurities remain in the anode. Elements such as americium and cerium, which are more electropositive than plutonium, concentrate in the electrolyte. To achieve these separations, however, the electrorefining cell must operate close to equilibrium. Thus, metal and salt phases must be molten and must be stirred effectively. Under these conditions, we can use standard free energy of formation values to estimate purification factors. ${ }^{15}$ To ensure that the cell is indeed operating under equilibrium, the electrolyzing current is interrupted periodically during a run, and the polarization potential or instantaneous back-emf is measured. Electrorefining is terminated automatically when the back-emf exceeds a preset value (See Ref. 8 for a discussion of the theory and operation of plutonium electrorefining cells). Electrorefining will continue as long as a plutonium-rich liquid phase is present at the anode metal-electrolyte interface. The back-emf process control ensures product purity while permitting high anode-dissolution yields. However, efficient stirring of both the anode metal and electrolyte are required to achieve conditions that permit effective use of back-emf process control.

\section{Electrorefining Cell Components}

1. Solvent System. An equimolar mixture of $\mathrm{NaCl}-\mathrm{KCl}$ was selected as the solvent system for the initial development studies' and is still used. The advantages of this system are

- its thermodynamic stability,

- its ease of handling (neither component is hygroscopic),

- its ready availability in a pure form, and

- its $650^{\circ} \mathrm{C}$ melting point, well suited to molten plutonium operations. ${ }^{2}$

2. Plutonium Electrolyte. The importance of the $\mathrm{Pu}^{+3}$ concentration in the electrolyte to the purification of plutonium metal is discussed in Ref. 8 . The following options are available for achieving the desired plutonium concentration.

(1) Addition of a plutonium halide salt such as $\mathrm{PuCl}_{3}, \mathrm{PuF}_{3}$, or $\mathrm{PuF}_{4}{ }^{5}$

(2) In situ electrolytic generation of $\mathrm{PuCl}_{3}{ }^{18}$

(3) Addition of $\mathrm{MgCl}_{2}{ }^{17,18}$
We have used all three halides listed in option (1). We used $\mathrm{PuCl}_{3}$ in the early work with vitrified alumina crucibles. Because $\mathrm{PuF}_{4}$ is readily available from our metal preparation facility, we have used it in virtually all of our kilogram-scale electrorefining runs. It has the advantage of being stable, nonhygroscopic, and readily prepared in a pure anhydrous condition. Before electrorefining, $\mathrm{PuF}_{4}$ is reduced to $\mathrm{PuF}_{3}$ by the plutonium metal anode.

$3 \mathrm{PuF}_{4}+\mathrm{Pu} \rightarrow 4 \mathrm{PuF}_{3}$.

Option (2) is ideally suited to purifying small amounts of ${ }^{238} \mathrm{Pu},{ }^{240} \mathrm{Pu},{ }^{242} \mathrm{Pu}$, and ${ }^{239} \mathrm{Pu}$ of unusual isotopic composition.* In the in situ generation, dc current is passed through an electrorefining cell with no stirring of metal or electrolyte. Under these conditions, the following reaction takes place. ${ }^{16.19}$

Anode $-\mathrm{Pu}(\ell) \rightarrow \mathrm{Pu}^{+3}$ (molten salt)

Cathode $-\mathrm{Na}^{+}$(molten salt) $\rightarrow \mathrm{Na}(\ell)$

The reduction of $\mathrm{Pu}^{+3}$ to metal competes with the reduction of $\mathrm{Na}^{+}$. About $50 \%$ of the current results in $\mathrm{Na}^{+}$reduction. After $\mathrm{PuCl}_{3}$ generation, the sodium is permitted to volatilize from the cathode and collect on the top furnace lid. This method has been used to purify 25,100 and $200 \mathrm{~g}$ of ${ }^{238} \mathrm{Pu}$. ${ }^{20}$ For kilogram amounts of special isotopes, option (3) is recommended. In this case, the following reaction takes place.

$3 \mathrm{MgCl}_{2}+2 \mathrm{Pu} \rightarrow 2 \mathrm{PuCl}_{3}+3 \mathrm{Mg}$.

This option has been used by workers at Rocky Flats** in electrorefining ${ }^{18}$ and has been studied extensively in molten salt extraction studies. ${ }^{21}$ The magnesium metal produced is volatilized slowly from the melt. The magnesium must be volatilized to avoid forming two immiscible liquid metallic

*We have also used this option in preparing high-purity ${ }^{237} \mathrm{~Np}$ metal by electrorefining (L. J. Mullins, unpublished data).

**Rockwell International, Energy Systems Group, P. O. Box 464, Golden, CO 80401. 
phases. (At $750^{\circ} \mathrm{C}$, the plutonium-magnesium system forms two immiscible liquid phases at $0.12 \%$ * magnesium. ${ }^{22}$ )

3. Crucible. Los Alamos electrorefining crucibles have been limited to $\mathrm{Al}_{2} \mathrm{O}_{3}, \mathrm{MgO}$, and $\mathrm{MgO}-\mathrm{Y}_{2} \mathrm{O}_{3}$. For a discussion of both ceramic and metal containers, see Ref. 2 . The latter body, fabricated by Los Alamos, was used in our development studies. However, the commercial bodies used in our facility are $\mathrm{MgO}$. $\left(\mathrm{Al}_{2} \mathrm{O}_{3}\right.$ can be substituted for $\mathrm{MgO}$ if fluoride is not present in the electrolyte. ${ }^{2}$ )

4. Cathode. Tungsten cathodes are used in all routine electrorefining operations. Their use contributes $\sim 50-80 \mathrm{ppm}^{* *}$ of tungsten to the product metal. ${ }^{23}$ For special preparations, such as those for the National Bureau of Standards, TaC cathodes that eliminate tungsten as an impurity and introduce $<20 \mathrm{ppm}$ tantalum and $<10 \mathrm{ppm}$ carbon are used. ${ }^{9}$

5. Stirrer. MgO stirrers are used to mix metals and salts in all routine operations. Tantalum stirrers have been used successfully at low dc currents, $<5 \mathrm{~A}$, but their use at $\leqq 9 \mathrm{~A}$ has resulted in tantalum contamination of the product and dissolution of the stirrer. $^{2}$

\section{E. OPERATING CONDITIONS}

1. Atmosphere. Because of the chemical reactivity of plutonium, tantalum, and tungsten metals at elevated temperatures, electrorefining takes place in an argon atmosphere. Loading operations are done in gloveboxes having a dry-air atmosphere.

2. Temperature. Because most electrorefining feeds have been plutonium - $1 \%$ gallium alloys, we chose the electrorefining temperature to optimize yields with this alloy. The plutonium-gallium phase diagram shows that the operating temperature should be above $720^{\circ} \mathrm{C} .^{8}$ To minimize container-corrosion problems and achieve acceptable yield, we set the electrorefining temperature at $740^{\circ} \mathrm{C} .^{5}$

3. dc Current. The Los Alamos plutonium electrorefining cells were wired for a maximum current of $30 \mathrm{~A}$. The actual current used for any particular

-All percentage values in this report are wt\%.

$*$ * $g$ of tantalum $/ 10^{\circ} \mathrm{g}$ plutonium run was calculated to permit termination of the run at a convenient time because the units were manned only 8 hours per day, 5 days a week. ${ }^{5}$ Thus, for a $3-\mathrm{kg}$ electrorefining operation starting at 10 a.m. on a Friday, the desired termination time would be about 8 a.m. the following Monday. The current used is calculated as follows.

$$
\begin{aligned}
\text { Current } & =\left(\frac{3000 \mathrm{~g} \mathrm{Pu}}{2.97 \mathrm{~g} \mathrm{Pu} / \mathrm{Ah}}\right)\left(\frac{1}{70 \mathrm{~h}}\right) \\
& =14.4 \mathrm{~A} .
\end{aligned}
$$

Thus, electrorefining $3 \mathrm{~kg}$ of plutonium in 46 hours requires $22 \mathrm{~A}$. Runs that could be completed during the normal work week were usually electrolyzed for 2 days.

The upper limit on the electrorefining current for the Los Alamos refining cell has never been established. Currents as high as $40 \mathrm{~A}$ were used in the development studies; ${ }^{24}$ however, most experiments were done at $25 \mathrm{~A}$. The maximum capability of the equipment for these studies was $50 \mathrm{~A}$. Back-emf measurements at $50 \mathrm{~A}$ indicate that polarization is not a problem at these currents. However, the effect, if any, of 50-A currents on yield and product purity was never established.

\section{Equilibration and Pre-electrolysis of Elec-} trolyte. Before passing electrorefining current, we equilibrate the anode metal with the electrolyte by stirring at $\sim 800 \mathrm{rpm}$. As discussed in Sec. I. D, this equilibration results in the reduction of $\mathrm{PuF}_{4}$ to $\mathrm{PuF}_{3}$. More important, however, this equilibration also transfers metallic ionic impurities from the salt melt to the anode pool, where they will remain during electrorefining. For example, assume $\mathrm{Fe}^{+3}$ is a contaminant in the electrolyte. The following oxidation-reduction will take place upon equilibration.

$\mathrm{Fe}^{+3}$ (salt) $+\mathrm{Pu}$ (anode) $\rightarrow \mathrm{Pu}^{+3}$ (salt) $+\mathrm{Fe}$ (anode).

In most runs, the cathode cylinder is coated with plutonium metal from an earlier run. To provide an additional driving force for the salt purification and 
to electropolish the cathode, a pre-electrolysis of the melt is done during equilibration. In this case, the tungsten cylinder is made anodic, and the plutonium feed metal is made cathodic (that is, the electrorefining current is reversed). The following reactions take place during this process.

Tungsten Cylinder: $\mathrm{Pu} \rightarrow \mathrm{Pu}^{+3}+3 e^{-} ;$

Plutonium Feed metal: $3 / \times M^{+x}+3 e^{-} \rightarrow 3 / \times M$,

where $M^{+x}$ is any metallic impurity less electropositive than plutonium, such as iron, nickel, chromium, etc.

\section{F. Feed Limitations}

Product purity is relatively independent of purity of the anode feed metal. Excellent separations from most metallic and nonmetallic elements are achieved even at impurity levels of a few per cent. ${ }^{8}$ The poorest separations have resulted with neptunium and americium. For example, in ${ }^{238} \mathrm{Pu}$ electrorefining runs with a ratio of $1 \mathrm{~g}$ plutonium as $\mathrm{PuCl}_{3}$ to $24 \mathrm{~g}$ plutonium as metal, the neptunium concentration was reduced from $4180 \mathrm{ppm}$ in the feed metal to $537 \mathrm{ppm}$ in the product. ${ }^{18}$ In ${ }^{239} \mathrm{Pu}$ electrorefining runs having a ratio of $1 \mathrm{~g}$ plutonium as $\mathrm{PuCl}_{3}$ to $33 \mathrm{~g}$ plutonium as metal, the americium was reduced from $143 \mathrm{ppm}$ in the feed metal to $20 \mathrm{ppm}$ in the product.

Product yields are sensitive to the purity of the anode feed metal because molten plutonium must be present at the anode-salt interface to prevent serious polarization. For example, an anode will go completely solid at $740^{\circ} \mathrm{C}$ at a gallium/plutonium atom ratio of 0.32 . Thus, electrorefining automatically will be terminated when gallium/plutonium $\leqq 0.32 .{ }^{8}$ Plutonium-metal phase diagrams can be used to calculate plutonium-anode dissolution values.s. ${ }^{\mathrm{B}}$

We prepare our anode-feed ingots by vacuum melting the metal, then pouring it into molds of the desired geometry. Vacuum melting removes volatile impurity metals such as calcium and magnesium.

\section{G. Factors Affecting Product Yields}

The yield of pure plutonium metal in electrorefining can be considered as two separate yields: (1) the fraction of plutonium dissolved at the anode, and (2) the fraction of plutonium deposited on the cathode and collected as a massive ingot.

As discussed in Sec.l. F, the fraction of plutonium dissolved at the anode depends on the nature and amounts of impurities present in the anode-feed metal. For unalloyed plutonium having a few thousand ppm impurities, $\sim 98 \%$ of the plutonium can be dissolved anodically. (In this case, the geometry of the anode container imposes the $98 \%$ limit). For plutonium alloyed with $1 \%$ gallium, $\sim 90 \%$ of the plutonium can be dissolved anodically.

The amount of plutonium deposited on the cathode and collected as a massive ingot depends on many factors. A small amount, $\sim 30 \mathrm{~g}$, of plutonium adheres to the cathode cylinder. However, because the cathode is usually reused in a subsequent run, this plutonium is not lost. The principal metal-collection losses result from metal adhering to the crucible walls and from plutonium shot that does not coalesce in the product ring. Loss to the crucible walls should be essentially constant. Loss as plutonium shot, however, can vary widely and depends on many factors.

In electrorefining, small plutonium droplets are deposited on the cathode. These droplets coalesce into larger drops that fall off the bottom of the cathode. Clean metal surfaces are essential to plutonium metal coalescence on the cathode. Thus, cathodes should be cleaned before use to ensure the absence of oxide films. Used cathodes containing plutonium are stored under argon when not in use. In addition, these cathodes are cleaned anodically during pre-electrolysis (see Appendix). Obviously, maintaining a pure argon atmosphere and using pure electrolyte are essential to ensuring the absence of reactive gases such as oxygen, nitrogen, and water vapor. The anode-metal feed should also be oxide-free. By taking these precautions, we can get collection yields of $>95 \%$. 


\section{DESCRIPTION OF THE LOS ALAMOS ELEC- TROREFINING FACILITY, EQUIPMENT, AND PROCEDURES}

Kilogram scale electrorefining operations were done in gloveboxes ER-1, 2, and 3 (Fig. 2). The fourth glovebox, ER-4, was equipped with a 20-ton hydraulic press to break product rings into pieces suitable for casting operations. This box was also equipped with an electrorefining furnace for special or unique runs on the $0.1-$ to $0.5-\mathrm{kg}$ scale. The fifth glovebox on the east side of the tunnel was inert and contained equipment for casting ultra-high-purity plutonium metal. The west side of the tunnel contained the introductory hood and glovebox, a weighing box, a pickling box, and a bag-out box. $\mathrm{NaCl}-\mathrm{KCl}$ salt castings were done in a salt-casting furnace located in the southeast corner. All of the electrical control equipment for operating the electrorefining and casting units was contained in the control panels on the east wall.

Electrorefining equipment and procedures are given in Los Alamos Group CMB-11 Procedure 430-MPP-R01 (see Appendix).

\section{RESULTS}

\section{A. Product Purity}

A general discussion of product purity is given in Sec. I. F. The electrorefined metal produced at TA-21 usually contained $<200 \mathrm{ppm}$ metallic impurities. Tungsten at an average value of $\sim 65 \mathrm{ppm}$ was the principal impurity. ${ }^{23}$ The tungsten results from attack of the tungsten-cathode cylinder by molten plutonium metal. For ultra-high-purity metal, <100 ppm impurities, we use a TaC cathode. ${ }^{9}$ Analysis of an impure metal feed and product using a tungsten cathode is given in Table I. This feed was less pure than the usual metal feed. However, results demonstrate the effectiveness of electrorefining in converting quite impure metal to high-purity metal. An impure plutonium-1\% gallium alloy containing $97.0 \%$ plutonium was electrorefined to yield a product containing $99.98 \%$ plutonium. Results for a more typical feed are given in Table II. In this case, the plutonium metal feed value was $98.8 \%$ and the product value was $99.98 \%$. The average purity for

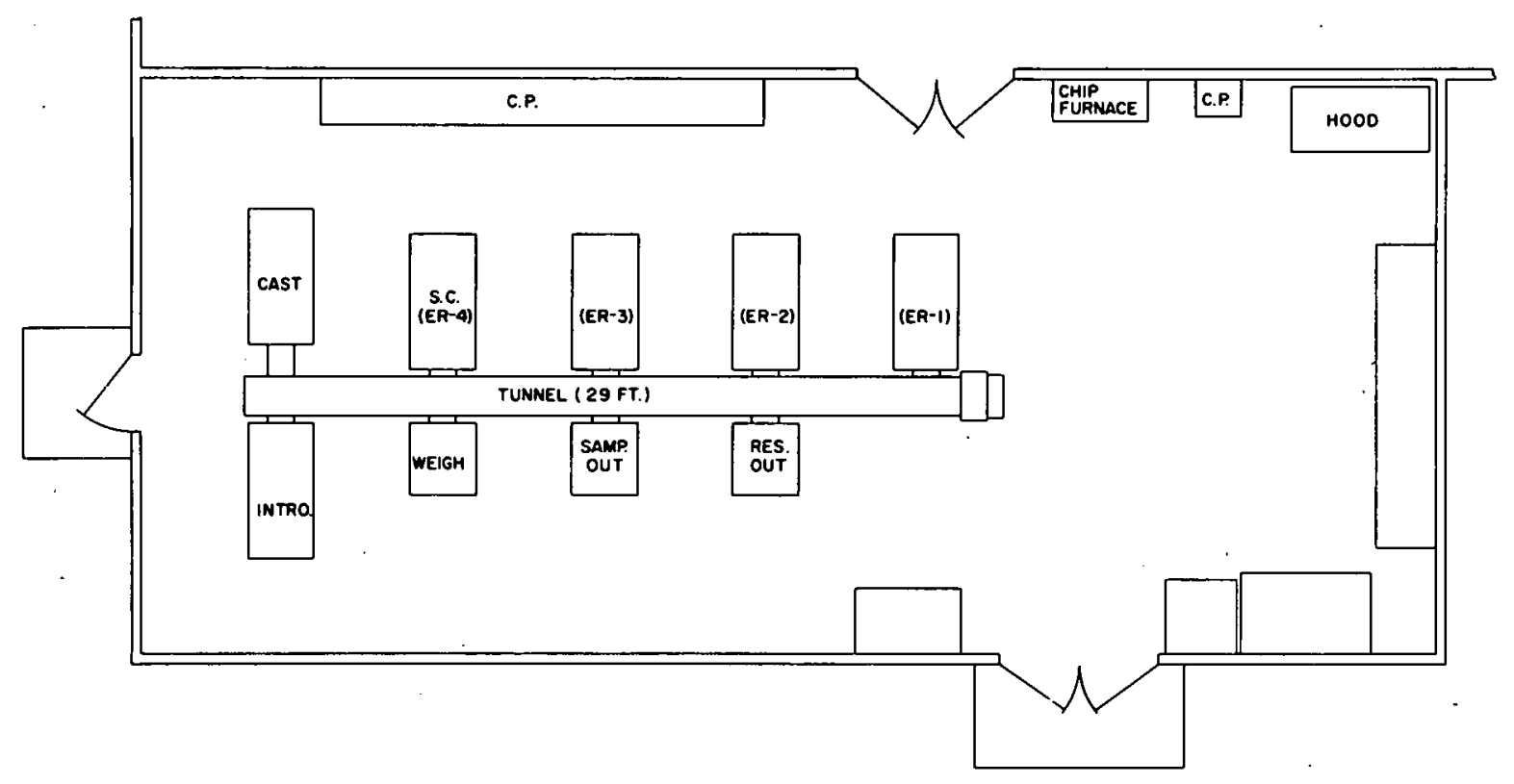

Fig. 2. Electrorefining room layout, TA-21. 


\begin{tabular}{lcc}
\hline \hline TABLE I. Purification of Plutonium, \\
Results With An Impure \\
Feed
\end{tabular}

all the feeds processed was $\sim 99.3 \%$ (Sec. III. B). This average purity value was obtained by dividing the total plutonium processed, $1916.6 \mathrm{~kg}$, by the total metal weight. In most cases, these plutonium values were "book" or by-difference values. Product metal purities were always $>99.9 \%^{23}$ and were determined directly by chemical analysis.

As discussed earlier, the behavior of impurities can be predicted qualitatively from the standard free energy of formation of corresponding chlorides. Elements whose chlorides have a standard free energy of formation $(\Delta F \circ)$ less negative than that of $\mathrm{PuCl}_{3}$ concentrate in the anode; those which are more negative concentrate in the electrolyte. The concentrations in Table III are from $\sim 650$ electrorefining runs. Because the degree of purification at any temperature depends on both the number of product throughputs (grams of product metal per grams of plutonium in salt) and the extent of anode depletion, only those runs for

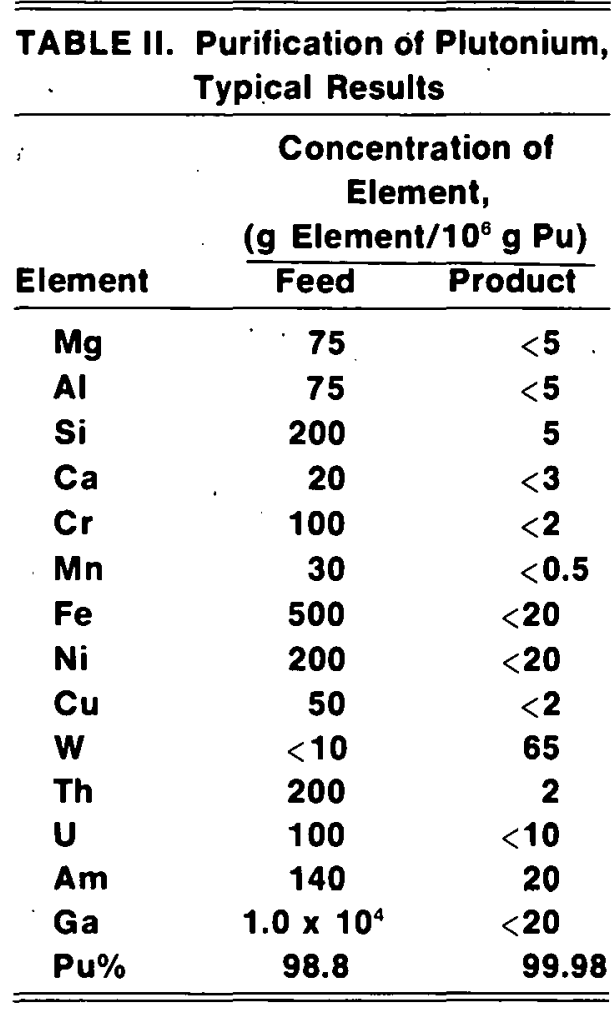

which the number of product throughputs exceed 20 , and the anode depletion exceeds $80 \%$ are listed. In most cases, the concentrations of the elements in the product were either undetectable or at values close to the limits of the analyses, so the values in Table III do not define the limits of the electrorefining process but merely suggest its capabilities. Further, this table does not imply that a pure product would necessarily be obtained in good yield if all impurities were present in the same feed at the indicated concentrations.

After the first few years of operation, we did not usually analyze product metal and feeds. However, product purity after casting continued to be measured, and these results are reported in Ref. 23.

\section{B: Plutonium Material Balances}

A summary of the plutonium flow through the TA-21 electrorefining facility from 1964 through 1977 is given in Table IV. During this period, $1930 \mathrm{~kg}$ of impure metal containing $1917 \mathrm{~kg}$ of plutonium was processed, yielding $1568 \mathrm{~kg}$ of high-purity product. All of these results are averaged in Table $V$. A further breakdown of the 
TABLE III. Behavior of Impurity Elements in Electrorefining

\begin{tabular}{|c|c|c|c|c|}
\hline \multirow[b]{2}{*}{ Element $^{\mathrm{a}}$} & \multirow{2}{*}{$\begin{array}{c}-\Delta \mathbf{F}^{\circ}, \\
\text { KCal per } \\
\text { Gram Atom } \\
\mathbf{C l}^{\mathrm{b}} \\
\end{array}$} & \multicolumn{2}{|c|}{$\begin{array}{c}\text { Concentration, } \\
\text { g Element/ } \\
10^{6} \mathrm{~g} \mathrm{Pu} \\
\end{array}$} & \multirow{2}{*}{$\begin{array}{c}\text { Element } \\
\text { Concentrated } \\
\text { In }\end{array}$} \\
\hline & & Feed & Product & \\
\hline Ir & 2 & 4500 & 110 & --- \\
\hline $\mathbf{N i}$ & 18 & 1000 & $<0.5$ & Anode \\
\hline $\mathrm{Cu}$ & 21 & 500 & $<1.5$ & Anode \\
\hline $\mathrm{Ta}$ & 27 & 5000 & 80 & Anode \\
\hline $\mathbf{P b}$ & 27 & 2000 & $<0$ & --- \\
\hline $\mathrm{Fe}$ & 27 & 25000 & 20 & Anode \\
\hline Si & 28 & 320 & $<5$ & Anode \\
\hline $\mathrm{Cr}$ & 32 & 340 & $<5$ & Anode \\
\hline $\mathbf{G a}$ & 32 & 10000 & $<25$ & Anode \\
\hline Mn & 41 & 70 & $<2$ & --- \\
\hline $\mathrm{Ti}$ & 43 & 15000 & 10 & --- \\
\hline Al & 46 & 2700 & $<5$ & Anode \\
\hline $\mathbf{U}$ & 54 & 330 & $<20$ & Anode \\
\hline $\mathrm{Zr}$ & 56 & 10000 & 14 & $\ldots$ \\
\hline Th & 59 & 1300 & 10 & Anode \\
\hline $\mathbf{P u}$ & 59 & --- & -.- & -.- \\
\hline $\mathrm{Ce}$ & 66 & 527 & $<25$ & Electrolyte \\
\hline Am & 67 & 850 & 82 & Electrolyte \\
\hline
\end{tabular}

${ }^{a}$ Listed in order of increasing stability of their chlorides.

${ }^{b}-\Delta F^{\circ}$ at $1000 \mathrm{~K}$ is tabulated. For elements having a multiplicity of oxidation states, the $-\Delta F^{\circ}$ for the most stable form of the chloride is given. Values are from Ref. 25.

Table IV data is given in Table VI, where the runs are averaged for each calendar year.

\section{Product Yields and Plutonium Utilization}

Yields for an electrorefining operation can be expressed in several ways. From a plant manager's viewpoint, the most useful number is product yield (PY), which is defined as

$P Y=100 \times \frac{P u_{p r}}{P u_{a l}}$

where

$\mathrm{Pu}_{\mathrm{pr}}=$ the weight of plutonium in the product ring, and
$\mathrm{Pu}_{\mathrm{al}}=$ the weight of plutonium in the anode feed

This yield gives the per cent conversion of impure-to-pure metal.

Plutonium utilization (PU) is defined as

$$
\mathrm{PU}=100 \times \frac{P u_{p r}+P u_{c t}}{P u_{a l}+P u_{s}+P u_{c l}},
$$

where

$\mathrm{Pu}_{\mathrm{cf}}=$ weight of plutonium on the cathode cylinder after the run,

$\mathrm{Pu}_{\mathrm{s}}=$ weight of plutonium added to the salt as $\mathrm{PuF}_{4}$, and

$\mathrm{Pu}_{\mathrm{cl}}=$ weight of plutonium on the cathode cylinds: before the run. 
TABLE IV. Flow of Materials, Electrorefining Summary

\begin{tabular}{|c|c|c|c|c|c|}
\hline \multirow[b]{3}{*}{ CY } & \multirow{3}{*}{$\begin{array}{c}\text { No. of } \\
\text { Runs }\end{array}$} & \multicolumn{4}{|c|}{ Materials Into Run (kg) } \\
\hline & & \multicolumn{2}{|c|}{ Anode Feed } & \multirow{2}{*}{$\begin{array}{l}\mathrm{PuF}_{4} \\
\mathrm{Pu}\end{array}$} & \multirow{2}{*}{$\begin{array}{c}\text { Cathode, } \\
\text { Pu }\end{array}$} \\
\hline & & Metal & $\mathbf{P u}$ & & \\
\hline 1964 & 38 & 115.391 & 113.747 & 2.865 & $0: 457$ \\
\hline 1965 & 41 & 123.449 & 122.583 & 4.018 & 0.779 \\
\hline 1966 & 25 & 74.897 & 74.620 & 2.751 & 0.578 \\
\hline 1967 & 47 & 133.147 & 132.226 & 4.658 & 0.941 \\
\hline 1968 & 44 & 125.180 & 124.288 & 4.384 & 1.119 \\
\hline 1969 & 45 & 130.607 & 130.158 & 4.451 & 1.151 \\
\hline 1970 & 56 & 164.323 & 163.185 & 5.588 & 1.591 \\
\hline 1971 & 63 & 182.631 & 181.565 & 6.100 & 1.698 \\
\hline 1972 & 89 & 263.948 & 262.284 & 8.710 & 2.657 \\
\hline 1973 & 33 & 100.789 & 99.906 & 3.234 & 0.957 \\
\hline 1974 & 54 & 163.579 & 162.268 & 5.175 & 1.079 \\
\hline 1975 & 33 & 95.598 & 94.987 & 1.724 & 0.707 \\
\hline 1976 & 46 & 146.003 & 145.304 & 1.482 & 1.459 \\
\hline 1977 & 39 & 110.522 & 109.500 & 1.170 & 0.995 \\
\hline Sums & 653 & 1930.064 & 1916.621 & 56.310 & 16.168 \\
\hline Mat'I & Tota & 1 In 10 & 0 & & \\
\hline
\end{tabular}

Bal

\begin{tabular}{lcrrrr} 
& & \multicolumn{5}{c}{ Materials Out of Run (kg) } \\
\cline { 3 - 6 } CY & $\begin{array}{c}\text { No. of } \\
\text { Runs }\end{array}$ & $\begin{array}{c}\text { Anode, } \\
\text { Pu }\end{array}$ & $\begin{array}{c}\text { Salt and } \\
\text { Cruc, Pu }\end{array}$ & $\begin{array}{c}\text { Cathode, } \\
\text { Pu }\end{array}$ & $\begin{array}{r}\text { Product } \\
\text { Ring, Pu }\end{array}$ \\
\hline 1964 & 38 & 17.181 & 13.370 & 0.951 & 85.567 \\
1965 & 41 & 10.007 & 12.121 & 1.381 & 103.871 \\
1966 & 25 & 7.567 & 8.379 & 0.953 & 61.050 \\
1967 & 47 & 14.862 & 16.131 & 1.649 & 105.183 \\
1968 & 44 & 10.542 & 14.092 & 1.552 & 103.605 \\
1969 & 45 & 10.256 & 13.777 & 1.552 & 110.175 \\
1970 & 56 & 14.369 & 17.535 & 1.862 & 136.598 \\
1971 & 63 & 20.581 & 19.243 & 2.703 & 146.836 \\
1972 & 89 & 26.494 & 28.522 & 3.534 & 215.101 \\
1973 & 33 & 8.577 & 12.755 & 1.567 & 81.198 \\
1974 & 54 & 14.439 & 22.439 & 2.036 & 129.608 \\
1975 & 33 & 7.764 & 10.402 & 1.195 & 78.057 \\
1976 & 46 & 11.790 & 12.970 & 2.028 & 121.467 \\
1977 & 39 & 8.728 & 11.291 & 1.630 & 90.016 \\
\hline Sums & 653 & 183.157 & 213.027 & 24.593 & 1568.322 \\
Total Pu Out $=1989.099$ & & & \\
\hline \hline
\end{tabular}




\begin{tabular}{lc}
\hline \hline \multicolumn{2}{|c}{ TABLE V. Average of 653 Runs, 1964-1977 } \\
\hline $\begin{array}{l}\text { Plutonium Into Run (g) } \\
\text { Metal Feed }\end{array}$ \\
Wt (g) & 2956 \\
Pu (g) & 2935 \\
Purity, \% & 99.29 \\
PuF & \\
Pu (g) & 86.2 \\
Cathode & \\
Pu (g) & 24.8 \\
Total Pu in, (g) & \\
Plutonium Out of Run (g) & 3046 \\
Anode, g Pu & 280 \\
Salt and Crucibles & 326 \\
Cathode & 38 \\
Product Ring & 2402 \\
Total Pu Out (g) & \\
\hline \hline
\end{tabular}

Thus, in the above equation, the denominator is the sum of all plutonium species put into the run, and the numerator is the sum of pure plutonium metal products that come out of the run. Because plutonium utilization contains the variable term $\mathrm{Pu}_{s}$, it is not as useful a number as product yield in evaluating electrorefining operations.

Product yields and plutonium utilizations are summarized in Table VII. The average product yield for the first year of operation was $75 \%$ but the average was $80 \%$ or higher for the following years. Large anode residues were the primary cause of lower yields the first year. Plutonium utilizations were about $2 \%$ lower than process yields reflecting the $100 \mathrm{~g}$ of plutonium added as $\mathrm{PuF}_{4}$ during the first 11 years of operation. Product yields and plutonium utilizations were virtually the same during the last 2 years of operation because only $30 \mathrm{~g}$ of plutonium was added as $\mathrm{PuF}_{4}$ (Table $\mathrm{VI}$ ). Lower requirements for americium removal permitted using less $\mathrm{PuF}_{4}$ in the last 2 years (Sec. III. E).

\section{Anode Depletion, Collection Efficiency, and Process Efficiency}

The two principal factors affecting product yield and plutonium utilization are anode depletion (D) and metal collection efficiency (CE).

$$
D=\frac{P u_{a l}-P u_{a f}}{P u_{a l}} \text {, }
$$

where
$\mathrm{Pu}_{\mathrm{af}}=$ weight of plutonium in the anode residue after run;

$C E=100 \times \frac{P u_{p r}+\Delta P u_{c}}{P u_{a 1}-P u_{a r}}$,

where

$$
\Delta \mathrm{Pu}_{\mathrm{c}}=\mathrm{Pu}_{\mathrm{cf}}-\mathrm{Pu}_{\mathrm{ci}}
$$

The value of anode depletion depends primarily on the purity of the feed metal (Sec. I. G). Because virtually all the feeds were $\mathrm{Pu}-1 \% \mathrm{Ga}$ alloys, the calculated value for $D$ is $0.89 .{ }^{8}$ The average value of D for CY 1964-1977 (Table VIII) was 0.905, good evidence that electrorefining equipment such as stirrers, back-emf control equipment, and furnace control equipment operated satisfactorily.

Values for metal-collection efficiency depend primarily on cathode design, operating techniques, and operational procedures (Sec. I. G). The average value of collection efficiency obtained in the research and development (R\&D) electrorefining studies was $95 \% .^{8}$ Collection efficiencies for the production facility are given in Table VIII. The average value over 14 years of operation was $90.87 \%$. Although the value is lower than the $95 \%$ value experienced in the R\&D work, we consider it to be a reasonable production value.

Process efficiency is defined as the product of $(D$ $X \mathrm{CE})$ and is therefore a measure of electrorefining efficiency, or

$P E=D \times C E=\frac{P u_{p r}+\Delta P u_{c}}{P u_{a l}}$. 
TABLE VI. Electrorefining, Yearly Average

\begin{tabular}{cccccc}
\hline & & \multicolumn{4}{c}{ Average of Materials Into Run (kg) } \\
\cline { 3 - 6 } CY & $\begin{array}{c}\text { No. of } \\
\text { Runs }\end{array}$ & \multicolumn{2}{c}{ Anode \begin{tabular}{c} 
Meed \\
\cline { 4 - 6 } Mul
\end{tabular}} & $\begin{array}{c}\text { Pu } \\
\text { Pu }\end{array}$ & $\begin{array}{c}\text { Cathode, } \\
\text { Pu }\end{array}$ \\
\hline 1964 & 38 & 3.037 & 2.993 & 0.075 & 0.012 \\
1965 & 41 & 3.011 & 2.990 & 0.098 & 0.019 \\
1966 & 25 & 2.996 & 2.985 & 0.110 & 0.023 \\
1967 & 47 & 2.833 & 2.813 & 0.099 & 0.020 \\
1968 & 44 & 2.845 & 2.825 & 0.100 & 0.025 \\
1969 & 45 & 2.902 & 2.892 & 0.099 & 0.026 \\
1970 & 56 & 2.934 & 2.914 & 0.100 & 0.028 \\
1971 & 63 & 2.899 & 2.882 & 0.097 & 0.027 \\
1972 & 89 & 2.966 & 2.947 & 0.098 & 0.030 \\
1973 & 33 & 3.054 & 3.027 & 0.098 & 0.029 \\
1974 & 54 & 3.029 & 3.005 & 0.096 & 0.020 \\
1975 & 33 & 2.897 & 2.878 & 0.052 & 0.021 \\
1976 & 46 & 3.174 & 3.159 & 0.032 & 0.032 \\
1977 & 39 & 2.834 & 2.808 & 0.030 & 0.026
\end{tabular}

Average of Materials Out of Run (kg)

\begin{tabular}{cccccc} 
CY & $\begin{array}{c}\text { No. of } \\
\text { Runs }\end{array}$ & $\begin{array}{c}\text { Anode, } \\
\text { Pu }\end{array}$ & $\begin{array}{c}\text { Salt and } \\
\text { Cruc, Pu }\end{array}$ & $\begin{array}{c}\text { Cathode, } \\
\text { Pu }\end{array}$ & $\begin{array}{c}\text { Product Ring, } \\
\text { Pu }\end{array}$ \\
\hline 1964 & 38 & 0.452 & 0.352 & 0.025 & 2.252 \\
1965 & 41 & 0.244 & 0.296 & 0.034 & 2.533 \\
1966 & 25 & 0.303 & 0.335 & 0.038 & 2.442 \\
1967 & 47 & 0.316 & 0.343 & 0.035 & 2.238 \\
1968 & 44 & 0.240 & 0.320 & 0.035 & 2.355 \\
1969 & 45 & 0.228 & 0.306 & 0.034 & 2.448 \\
1970 & 56 & 0.257 & 0.313 & 0.033 & 2.439 \\
1971 & 63 & 0.327 & 0.305 & 0.043 & 2.331 \\
1972 & 89 & 0.298 & 0.320 & 0.040 & 2.417 \\
1973 & 33 & 0.260 & 0.386 & 0.047 & 2.461 \\
1974 & 54 & 0.267 & 0.416 & 0.038 & 2.400 \\
1975 & 33 & 0.235 & 0.315 & 0.036 & 2.365 \\
1976 & 46 & 0.256 & 0.282 & 0.044 & 2.640 \\
1977 & 39 & 0.224 & 0.290 & 0.042 & 2.308 \\
\hline \hline
\end{tabular}

\section{E. Plutonium Tetrafluoride Addition}

The amount of plutonium added to the electrolyte depends primarily upon the requirements for americium removal. During the first 11 years of operation, $0.10 \mathrm{~kg}$ of plutonium as $\mathrm{PuF}_{4}$ was added to remove the americium from $3.00 \mathrm{~kg}$ of plutonium feed. The americium decontamination factor (DF) for this case is $\sim 10$, where

$\mathrm{DF}^{\prime}=\frac{\mathrm{ppm} \text { americium in anode feed }}{\mathrm{ppm} \text { americium in cathode product }}$. 


\begin{tabular}{|c|c|c|}
\hline \multirow[t]{3}{*}{ TABLE } & \multicolumn{2}{|c|}{$\begin{array}{l}\text { II. Yearly Average o } \\
\text { Product Yields an } \\
\text { Process Efficiencie }\end{array}$} \\
\hline & \multicolumn{2}{|c|}{ Yearly Average } \\
\hline & $\begin{array}{l}\text { Product } \\
\text { Yield } \\
(\%) \\
\end{array}$ & $\begin{array}{c}\text { Plutonium } \\
\text { Utilization } \\
(\%)\end{array}$ \\
\hline 1964 & 75.24 & 73.93 \\
\hline 1965 & 84.72 & 82.62 \\
\hline 1966 & 81.81 & 79.54 \\
\hline 1967 & 79.56 & 77.52 \\
\hline 1968 & 83.36 & 81.02 \\
\hline 1969 & 84.65 & 82.27 \\
\hline 1970 & 83.70 & 81.26 \\
\hline 1971 & 80.88 & 78.98 \\
\hline 1972 & 82.02 & 79.90 \\
\hline 1973 & 81.30 & 79.52 \\
\hline 1974 & 79.87 & 78.12 \\
\hline 1975 & 82.18 & 81.36 \\
\hline 1976 & 83.57 & 83.28 \\
\hline 1977 & 82.19 & 82.05 \\
\hline
\end{tabular}

TABLE VIII. Yearly Averages of Anode Depletion (D), Collection Efficiency (CE) and Process Efficiency (PE)

\begin{tabular}{cccc}
\hline & \multicolumn{3}{c}{ Yearly Average } \\
\cline { 2 - 4 } CY & D & CE (\%) & PE (\%) \\
\hline 1964 & 0.8490 & 89.14 & 75.68 \\
1965 & 0.9184 & 92.79 & 85.22 \\
1966 & 0.8985 & 91.61 & 82.31 \\
1967 & 0.8877 & 90.23 & 80.10 \\
1968 & 0.9150 & 91.49 & 83.71 \\
1969 & 0.9212 & 92.19 & 84.93 \\
1970 & 0.9118 & 91.98 & 83.87 \\
1971 & 0.8865 & 91.86 & 81.43 \\
1972 & 0.8989 & 91.62 & 82.36 \\
1973 & 0.9141 & 89.59 & 81.89 \\
1974 & 0.9111 & 88.31 & 80.46 \\
1975 & 0.9183 & 90.05 & 82.69 \\
1976 & 0.9190 & 91.35 & 83.95 \\
1977 & 0.9202 & 89.94 & 82.76 \\
\hline \hline
\end{tabular}

Requirements for americium removal during the last 2 to 3 years of operation relaxed, and $0.030 \mathrm{~kg}$ of plutonium as $\mathrm{PuF}_{4}$ was sufficient to achieve the desired DF of 3.

\section{F. Equipment Failures}

Premature terminations of electrorefining runs have resulted from the following causes.

1. Broken ceramic stirrer

2. Broken cathode cylinder

3. Broken anode rod

4. Broken crucible

5. Operator's inability to position hardware

6. Furnace failure

The failure rate from all causes amounted to $12 \%$ of all runs. Of these failures, $33 \%$ were due to broken stirrers, $29 \%$ to broken cathodes, $9 \%$ to 2 broken anode rods, $11 \%$ to crucibles, $7 \%$ to hardware positioning problems, and $11 \%$ to furnace failures.

The fragile anode stirrer is the weakest component of the electrorefining equipment. Breakage, when it occurs, usually takes place during the lowering of the stirrer into the crucible. The fracture plane is usually at the junction of the magnesia stirrer and the stainless steel collet.

When the tungsten cylinder breaks, the break occurs in the area where the slotted tantalum rod is joined to the tungsten cylinder. Strict adherance to drawing specifications is required to minimize mechanical stresses. Tighter fabrication specifications would likely eliminate this problem.

\section{G. Casting of Electrorefined Metal}

The casting of electrorefined metal is outlined in Ref. 23, which provides an excellent summary of foundry practices and analytical results. The metal is melted under vacuum in an oxidized tantalum crucible and is bottom-poured into a variety of molds. Oxidized tantalum, graphite coated with calcium fluoride, aluminum, and copper are used routinely as molds with virtually no contamination of the plutonium metal. 


\section{H. Recycle of Electrorefining Residues}

Depleted anodes, salts, and crucibles are the principal residues created in the electrorefining operation. To recover depleted anodes, we burn the metal to oxide, dissolve the oxide in $\mathrm{HNO}_{3}-\mathrm{HF}$, and purify the plutonium by anion exchange.$^{2 \theta}$ Most of the crucible pieces are separated from salt or chloride melt and are leached with $10 \mathrm{M} \mathrm{HNO}_{3}$ $-0.05 \mathrm{M} \mathrm{HF}$. The chloride melt and the magnesia pieces from the anode cup are leached with $2 \mathbf{M}$ $\mathrm{NaOH}$. This treatment dissolves the $\mathrm{NaCl}-\mathrm{KCl}$ salt and precipitates plutonium as the hydroxide that is subsequently dissolved in nitric acid and purified by anion exchange.

\section{SUMMARY AND RECOMMENDATIONS}

It is very surprising that virtually no changes were made to electrorefining equipment or procedures during the 14 years of operation at TA-21. This was due to the successful operation of the facility. A part-time staff of three produced more than $1700 \mathrm{~kg}$ of high-purity metal in a relatively small, inexpensive facility. The facility's output was limited by the availability of metal feed rather than by its capacity, which was $10 \mathrm{~kg}$ plutonium per week. Equipment failure, other than that discussed in Sec. III. F, was rare, and product quality was always high. Indeed, after the first few years of operation, chemical analysis of the product metal was discontinued, and the metal went directly to the foundry. Subsequent analysis of finished parts has continued to show the same high chemical purity. The small labor requirements and elimination of the need for chemical analysis of both metal feeds and products have resulted in low unit costs for high-purity plutonium metal. Though the facility has been very successful, we recommend further study to improve

- process efficiencies,

- operational efficiencies, and

- recycling of process residues.

\section{A. Improve Process Efficiency}

Process efficiency could be increased by improving collection efficiency and anode depletion (Sec.
III. D). A better understanding of the mechanisms of cathode deposition and product coalescence could optimize collection efficiency. An alternative to mechanistic studies is an in-depth study of the variables involved in collection.

Efficient anode stirring is essential to high anode depletion. The present ceramic stirrer is adequate for good anode depletion with relatively pure $\mathrm{Pu}-1 \% \mathrm{Ga}$ alloys. In this case, the anode contains only a liquid phase at the beginning of a run. The appearance of a solid $\mathrm{Pu}_{3} \mathrm{Ga}$ phase does not interfere with the progress of the run so long as some liquid phase is present. Satisfactory anode depletion has been difficult for anodes that split into two immiscible liquid phases during the run. Our present ceramic stirrer does not mix or turn over these phases adequately so electrorefining terminates prematurely. Therefore, we need a better stirrer.

\section{B. Improve Operational Efficiency}

The operational efficiency could be improved by

- increasing the plutonium anode loading,

- decreasing the time of a run, and

- decreasing the failure rate.

Material specifications for the anode-feed metal were established by specifying $21 / 4$ in.-diam by 3-in.-tall dimensions for the cast cylinder. ${ }^{5}$ Thus, an alpha-phase ingot of these dimensions would weigh $\sim 3.7 \mathrm{~kg}$ and a delta-phase ingot would weigh $\sim 3.0 \mathrm{~kg}$. Both these weights can be increased to $4 \mathrm{~kg}$ of plutonium by specifying that the plutonium be cast into a 2.5-in. diam die.

Improvements in critical mass measurements ${ }^{27}$ have resulted in higher mass units for foundry operations at Los Alamos. Present foundry limits are $6 \mathrm{~kg}$ plutonium for delta phase and $4.5 \mathrm{~kg}$ for alpha phase. These limits should be examined for electrorefining operations.

Time of a run can be decreased by increasing dc current and increasing heating and cooling rates. As discussed in Sec. I. E, the electrolyzing current has never been optimized. The use of ceramic components precludes very rapid heating and cooling rates. The present very slow heating rate was selected for operational convenience but never optimized. Cooling rates could be increased by equipment modification. 
The $12 \%$ failure rate probably could be reduced to $<5 \%$ by redesigning some of the electrorefining hardware (Sec. III. F).

\section{Nonaqueous Recycle of Process Residues}

The recovery of electrorefining residues by aqueous methods requires more labor than electrorefining and casting operations. This effort might be reduced by using pyrochemical techniques. Anode heels and salt residues are prime candidates for pyrochemical processing.

The chemical composition of a depleted anode depends upon the purity of the electrorefining feed metal because virtually all of the impurities remain in the anode. Thus, for a feed containing $98 \%$ plutonium, $1 \%$ gallium, and $1 \%$ other impurities, we expect a depleted anode containing $83.3 \%$ plutonium, $8.3 \%$ gallium, and $8.4 \%$ other impurities. This anode is still a rich source of plutonium metal from which plutonium could be isolated either by the $\mathrm{ZnCl}_{2}$ pyrochemical method ${ }^{\mathbf{2 8 . 2 9}}$ or by further electrolytic refining (a solid anode process or metal solvent process). The plutonium from these processes need not be of high purity. The metal could serve as feed to the existing electrorefining process.

Electrorefining salts are also prime candidates for pyrochemical processing. These salts consist primarily of $\sim 1200 \mathrm{~g} \mathrm{NaCl}-\mathrm{KCl}, \sim 300 \mathrm{~g}$ plutonium, and $\sim 3 \mathrm{~g}$ americium. The plutonium is present as both salt and metallic shot.

Recovery of plutonium from the crucible surfaces is now done by leaching or washing the crucible fragments in acid. This method is quite efficient and is probably superior to alternate pyrochemical techniques.

\section{Summary}

This report discusses how the Los Alamos Electrorefining Facility has performed admirably in recycling metallic plutonium scrap. Large amounts of high-purity metal were produced with minimal labor. However, the report also indicates that an update is overdue. A modest investment in process development could increase dramatically the effectiveness of this recycling tool.

\section{REFERENCES}

1. L. J. Mullins, J. A. Leary, and C. W. Bjorklund, "Large Scale Preparation of High Purity Plutonium Metal by Electrorefining," Los Alamos Scientific Laboratory report LA-2441-MS (September 1960).

2. L. J. Mullins, J.A. Leary, A. N. Morgan, and W. J. Maraman, "Plutonium Electrorefining," Los Alamos Scientific Laboratory report LA-2666 (June 1962).

3. L. J. Mullins, J. L. Leary, A. M. Morgan, and W. J. Maraman, "Plutonium Electrorefining," I\&EC Process Design Develop. 2, 20 (1963).

4. L. J. Mullins and J. A. Leary, "Multikilogram Electrorefining of Plutonium Metal," in Electrochemistry, Proc. Aust. Conf. Electrochem., Sydney, 13-15 February and Hobart 18-20 February, 1963 (Oxford, Pergamon Press, 1964), pp. 923-931.

5. L. J. Mullins, J. A. Leary, and A. N. Morgan, "Operating Instructions, Procedures, and Equipment for the Los Alamos Plutonium Refining Plant," Los Alamos Scientific Laboratory report LA-2981 (December 1963).

6. L. J. Mullins, J. A. Leary, and A. N. Morgan, "Large Scale Electrorefining of Plutonium from Plutonium Iron Alloys," Los Alamos Scientific Laboratory report LA-3029 (April 1964).

7. L. J. Mullins and J.A. Leary, "Fused Salt Electrorefining of Molten Plutonium and Its Alloys," Los Alamos Scientific Laboratory report LA-3118 (November 1964).

8. L. J. Mullins and J. A. Leary, "Fused Salt Electrorefining of Molten Plutonium and its Alloys by the LAMEX Process," I\&EC Process Design Develop. 4, 394 (1965).

9. J. A. Leary and L. J. Mullins, "Preparation of Ultra-High Purity Plutonium," Los Alamos Scientific Laboratory report LA-3346-MS (August 1965). 
10. L. J. Mullins, J. A. Leary, C. W. Bjorklund, and W. J. Maraman, "Plutonium Electrorefining Cells," U. S. Patent No. 3,098,028 (July 26, 1963).

11. L. J. Mullins and J.A. Leary, "Method for Producing Ultra High Purity Plutonium Metal," U. S. Patent No. 3,281,338 (October 25, 1966).

12. J. A. Leary, L. J. Mullins, and J. F. Buchen, "Method and Apparatus for Improving Recovery of Plutonium-Gallium Alloys by Electrorefining," U. S. Patent No. 3,417,002 (December 12, 1968).

13. J. M. Steele, "Electrorefining in Aqueous Electrolytes," in Industrial Electrochemical Processes, A. T. Kuhn, Ed. (New York, Elsevier Publishing Co., 1971), pp. 219-244.

14. P. F. Hart and A. W. D. Hills, "Electrorefining in Molten Salts," in Industrial Electrochemical Processes, A. T. Kuhn, Ed. (New York, Elsevier Publishing Co., 1971 ), pp. 245-261.

15. J. A. Leary and L. J. Mullins, "Practical Application of Thermodynamics to Plutonium Process Reactions at High Temperatures," in Thermodynamics Vol. I (Vienna, International Atomic Energy Agency, 1966), pp. 459-471.

16. L. J. Mullins and J. A. Leary, "Plutonium-238 for Biomedical Application," Nucl. Appl. 6, 287-297 (1969).

17. L. J. Mullins and J.A. Leary, "Removal of Fission Product Elements by Slagging," Ind. Eng. Chem. 52, 227-230 (1960).

18. J. L. Long and R. D. Schweikhardt, "Plutonium Electrorefining at Rocky Flats," Dow Chemical Company, Rocky Flats Division report RFP-871 (April 1967).

19. L. J. Mullins, "Preparation and Evaluation of Medical-Grade Plutonium-238 Fuels, July 1, 1967-June 30, 1978," Los Alamos Scientific Laboratory report LA-4940 (October 1972).
20. C. L. Foxx and L. J. Mullins, "Plutonium-238 Fuel and Heat Source Development Work for Nuclear-Powered Artificial Heart Program, July 1-September 30, 1976," Los Alamos Scientific report LA-6669-PR (February 1977).

21. J. B. Knighton, R. G. Auge, J. W. Berry, and R. C. Francini, "Molten Salt Extraction of Americium from Plutonium Metal," Rockwell International report RFP-2356 (March 1976).

22. W. Knoch, J. B. Knighton, and R. K. Steunenberg, "Contrlbution to the Plutonium-Magnesium Phase Diagram," in Nuc. Metall. 15, Symposium on Reprocessing of Nuclear Fuels, P. Chotti, Ed., U. S. Atomic Energy Commission/Division of Technical Information CONF-690801, 1969.

23. D. R. Harbur, J. W. Anderson, and W. J. Maraman, "Unusual Problems Encountered in Casting High Density-High Purity Plutonium," Mod. Cast. 53, 60-64 (1968).

24. L. J. Mullins, J. A. Leary, and A. N. Morgan, "Plutonium Electrorefining," Los Alamos $\mathrm{Na}$ tional Laboratory internal document, CMB-11-65, monthly report for the period May 17-June 17, 1963.

25. A. Glassner, "The Thermochemical Properties of the Oxides, Fluorides, and Chlorides to 2,500 K," Argonne National Laboratory report ANL-5750 (1957).

26. E. L. Christensen and W. J. Maraman, "Plutonium Processing at the Los Alamos Scientific Laboratory," Los Alamos Scientific report LA-3542 (April 1969).

27. D. R. Smith and W. O. Geer, "Critical Mass of a Water Reflected Plutonium Sphere," Nucl. Appl Tech. 7, 405-408 (1967).

28. J. G. Reavis, J. A. Leary, and K. A. Walsh, "Non-Aqueous Dissolution of Massive Plutonium;" U. S. Patent 2,886,410 (May 12 , 1959). 
29. R. G. Auge, J. B. Knighton, and R. E. Giebel, "Induction-Heated Tilt-Pour Furnace," in RFP 2870,. Chemistry Research and Develop- ment Progress Report, May through October, 1978 , p. 14 (1979).

\section{APPENDIX \\ OPERATING PROCEDURES FOR \\ ELECTROREFINING OF PLUTONIUM METAL}

The operating procedures described here summarize and revise those given in Ref.5. The purpose of the electrorefining operation is to convert impure plutonium metal and alloys to high-purity metal.

The maximum permissible plutonium content of one electrorefining glovebox is $4 \mathrm{~kg}$.

\section{MATERIAL SPECIFICATIONS}

A. Ceramic Cell - vitrified magnesium oxide crucibles specified in Los Alamos Drawing 26Y-72325, Rev. A, and specification CMB-11-76-8.

B. Ceramic Stirrer - vitrified magnesia as specified in Los Alamos Drawing $26 Y-72500, C-1$, and specification CMB-11-76-8.

C. Anode Feed Metal - cylinder with maximum dimensions of 2-1/4-in.-diam by 3 in. tall.

D. Electrolyte - $\mathrm{NaCl}-\mathrm{KCl}$ cylinder, 3-1/2 in. diam, weighing $1.4 \mathrm{~kg}$; hole, 1 -in.-diam by $3 \mathrm{in}$. deep, drilled in the curved end of the cylinder. The amount of $\mathrm{PuF}_{3}$ or PuF 4 used depends on the quality of anode feed (see Ref. 5, pp. 14 and 26). For most routine runs, $39.5 \mathrm{~g}$ of $\mathrm{PuF}_{4}$ is used. The alkali halides are analytical grade reagents, and the fluoride should contain $<1000 \mathrm{ppm}$ of metallic impurities.

\section{EQUIPMENT SPECIFICATIONS}

A. Electrorefining Furnace Assembly - The furnace assembly is shown in Fig. A-1. The construction materials for various components are given below.

Part No.

\begin{tabular}{lcl}
\multicolumn{1}{c}{ Item } & (Fig. A-1) & \multicolumn{1}{c}{ Material } \\
\hline Furnace tube & 9 & Inconel 600 \\
Cathode & 13 & Tungsten \\
Anode & 36 & Tungsten \\
Stirrer & 14 & MgO \\
Safety can & 12 & Tantalum \\
Thermal insulator & 37 & MgO \\
Loading can & 32 & Stainless steel, \\
& & type 316 \\
Crucible & 11 & MgO \\
Pre-electrolysis rod & Not shown & Tungsten
\end{tabular}

B. Instrumentation-The instrument stacks contain the following equipment.

1. Automatic back-emf sampler.

2. Ampere-hour meter.

3. dc power supply, ammeter, voltmeter.

4. Furnace programmer.

5. Temperature recorder.

6. Current, voltage recorder.

7. Timer for starting program. 
C. Resistance Furnace - The electrorefining cell is heated by a 6 -in.-id resistance furnace, Lindberg Type 6015S. The furnace is thermally interlocked to negative pressure cooling water. The maximum attainable temperature is established by setting the Variac at $80 \%$. Two Platinell II thermocouples are installed in the center of the furnace. One of these thermocouples goes to the furnace programmer, and the other goes to the temperature recorder.

D. Safety Features - The electrorefining equipment has these safety features to permit full-time unattended operation.

1. Automatic back-emf sampler.

2. Heat sensor interlock, furnacecooling, water-return line.

3. Tantalum safety can.

4. Water-cooled bottom plate on glovebox furnace can.

5. Thermocouple burn-out protection on controller thermocouple.

6. Variac control of maximum furnace temperature.

\section{OPERATING PROCEDURE}

A. Inspection of Equipment

The stirrer, cathode, and anode should be inspected visually for mechanical defects. Use a resistance meter to check the integrity of the cathode and anode insulators.

B. Loading of Furnace (Fig. A-1)

1. Place $\mathrm{MgO}$ plate (37) in stainless steel can (32).

2. Place tantalum safety crucible (12) in stainless steel can.

3. Place magnesia cell (11) carefully in tantalum safety crucible.

4. Place metal feed cylinder carefully in anode cup.

5. Place stainless steel can in furnace tube (9).

6. Place head flange (24) on furnace tube and lower cathode (13) to bottom of crucible to assure proper

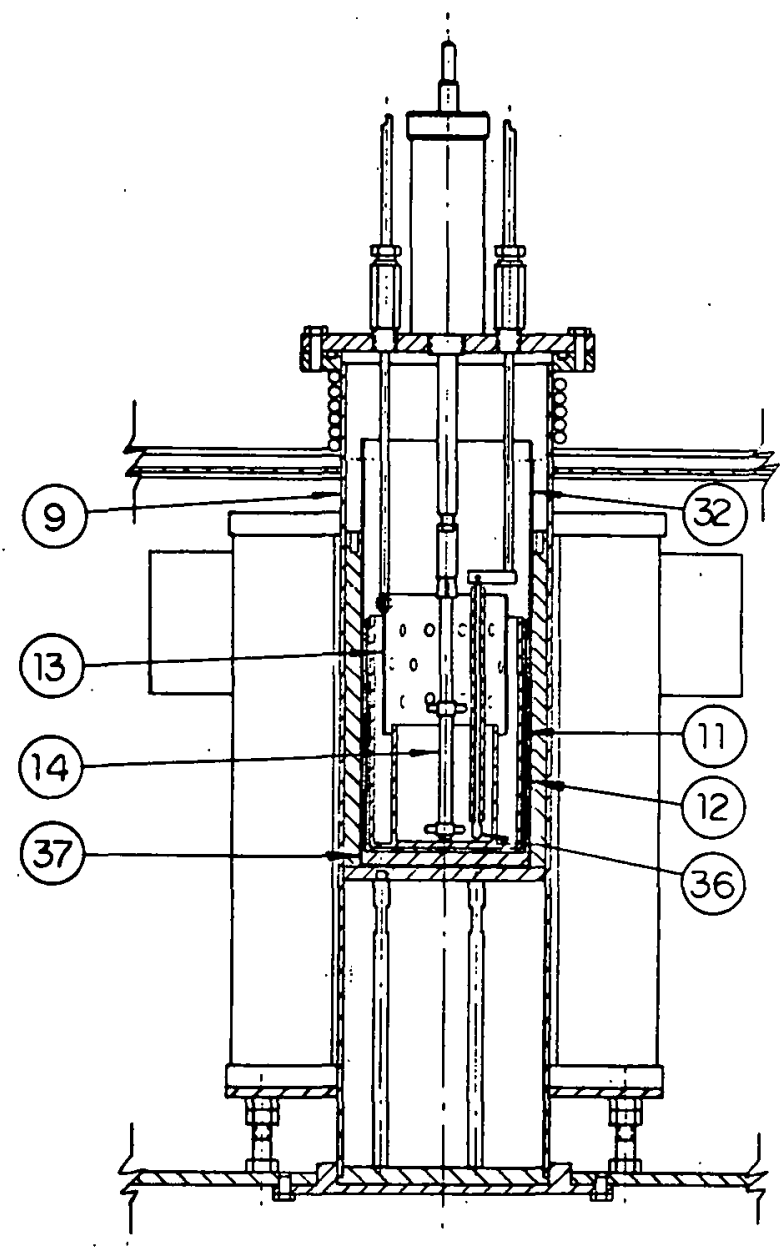

Fig. A-1. Assembly, Electrorefining Furnace, Los Alamos Drawing 26Y-79819.

alignment. If cathode cannot be lowered to this point, consult supervisor.

7. Raise cathode and remove head flange.

8. Place $\mathrm{NaCl}-\mathrm{KCl}$ casting in magnesia cell.

9. Place $\mathrm{PuF}_{4}$ in cavity of $\mathrm{NaCl}-\mathrm{KCl}$ casting.

10. Seal furnace tube by placing head flange provided with stirrer, anode rod, cathode, and pre-electrolysis rod on furnace tube.

11. Bolt down flange and connect gas fitting to inert gas line.

12. Apply vacuum to furnace tube and check for vacuum tightness by closing vacuum valve and observing the 
leak rate shown by vacuum gauge. If any evidence of leakage is seen, consult supervisor.

13. Flush system three times with argon and leave system under argon. (Note, the argon gas is purified by the uranium chip furnace.)

C. Furnace Heating Cycle

1. Check furnace tube cooling water; negative pressure circulating water is used.

2. Check positive pressure cooling water on glovebox furnace can.

3. Turn on resistance furnace or set timer to do so. The cam provided on the controller provides a heating rate of $50^{\circ} \mathrm{C}$ /hour and a hold at $\sim 880^{\circ} \mathrm{C}$. (Note, the furnace hold temperature keeps the electrolyte temperature at $740^{\circ} \mathrm{C}$. Calibrations are made at the direction of and under the supervision of the responsible staff member.)

4. When furnace controller has reached a temperature of $880^{\circ} \mathrm{C}$, turn off controller cam drive.

5. Lower cathode cylinder to bottom of crucible.

6. Lower anode rod to bottom of anode cup with anode rod near center of anode cup; rotate anode rod to side of anode cup; tighten packing nut.

7. Lower pre-electrolysis rod if required; position end below rim of anode cup.

8. Raise cathode to position shown in Fig. A-1. (Bottom rim of cathode is positioned $1 / 4 \mathrm{in}$. below rim of anode cup).

9. Lower stirrer to bottom of anode cup; position it $\sim 1 / 32$ in. off bottom.

D. Pre-Electrolysis Using Pre-Electrolysis Rod

1. Connect pre-electrolysis rod to negative terminal of dc power supply.

2. Connect anode rod (27) to positive terminal of dc power supply.

3. Turn on stirrer. It should rotate at $\sim 800 \mathrm{rpm}$.
4. Stir 1 hour.

5. Turn on current-voltage recorder.

6. Turn on dc power supply and adjust current to $2 \mathrm{~A}$. This should require a potential* of between 0.2 and $0.4 \mathrm{~V}$.

7. After passing current for a few minutes, check and record the back-emf (back-emf should be 0.0 $-0.1 \mathrm{~V})$.

8. Pass 2 A for 1 hour; shut off current; shut off stirrer.

9. Disconnect and raise the pre-electrolysis rod.

10. Connect negative terminal of dc power supply to cathode rod.

E. Pre-Electrolysis Using Cathode from Previous Run

1. Connect negative terminal to cathode rod (29).

2. Switch handle on dc power supply to reverse electrorefining position (REV) before pre-electrolysis.

3. Same as steps 3-8 in Sec. D.

4. Upon completion of pre-electrolysis, switch handle to normal position.

F. Electrorefining

1. Turn on stirrer.

2. Pass current at a value that will permit termination of the electrorefining at a convenient time.** Resistance (V/A) should be $0.15 \Omega$.

3. Turn on automatic back-emf sampler. Set sampler dial at $0.3 \mathrm{~V}$.

4. After several minutes operation, measure back-emf (back-emf should be 0.0-0.2 V).

5. Equipment should be checked for proper operation periodically (at

*The potentials are measured across the lead wires carrying current from the dc power supply to the electrorefining cell.

**Example of current calculations:

Assume: charge of $3.2 \mathrm{~kg} \mathrm{Pu}$ electrolysis to terminate 46 hours later;

$$
\begin{aligned}
\text { Current } & =\left(\frac{3200 \mathrm{~g} \mathrm{Pu}}{2.97 \mathrm{~g} \mathrm{Pu} / \mathrm{A} \text { hour }}\right) \frac{1}{46 \text { hour }} \\
& =23.4 \mathrm{~A}
\end{aligned}
$$


least twice) during the normal 8-hour working day. The check should include

a. observation of the argon-gas-flow meter. (If more than $0.5 \mathrm{ft}^{3}$ of gas is being used per hour, the stirrer packing gland should be tightened.)

b. Check cell resistance.

c. Inspect stirrer operation visually; stirrer should rotate at $\sim 800 \mathrm{rpm}$. Electrorefining is terminated automatically by the back-emf sampler.

G. Symptoms of Electrorefining Failure

1. Back-emf $\leqq 0.00 \mathrm{~V}$ and resistance $<0.08 \Omega$. This condition can be caused by either a broken anode cup or a short-out of anode and cathode. Observance of the operating instructions will eliminate the latter possibility. If the anode cup is broken, stop the run as directed in Sec. $\mathrm{H}$.

2. Back-emt $>0.2 \mathrm{~V}$ and resistance $>0.3 \Omega$. This condition is caused by improper positioning of the anode rod, not positioning it in the anode metal. Following the operating instructions will eliminate this failure.

3. Back-emt $>0.2 \mathrm{~V}$ and resistance $<0.08 \Omega$. This condition is caused by improper positioning of the anode rod, not placing it in the anode metal and shorting it out against the cathode. Following the operating instructions will eliminate this failure.

H. Terminal Cycle

1. Stop the stirrer when electrorefining ends.

2. Disconnect anode and cathode leads.

3. Raise anode rod and stirrer" nut of crucible.

* $D$ on stirrer-15 in. ( $D$ is the distance from flange (24) to end of stirrer shaft).
4. Agitate the product metal by gently lowering cylindrical cathode to bottom of cell then raising its electrolysis position. Repeat operation $\sim 100$ times, exercising care not to rotate the cathode rod or to hit the bottom of the cell.

5. Reposition cathode as shown in Fig. A-1.

6. After $\sim 2$ hours, raise cathode.*

7. Approximately 4 hours after electrorefining ends, cut off furnace power.

I. Unloading

1. Do not unload until cell temperature is $\angle 50^{\circ} \mathrm{C}$.

2. Carefully unbolt and remove furnace head.

3. Remove stainless steel can from furnace tube with handle.

4. Remove cell from tantalum safety can.

5. Break crucible and salt away from product ring and anode residue.

6. Record weights of product, anode residue, and cathode.

7. Sample ring if required.

8. Transfer materials as in DYMAC Operating Procedure 421-MPP.

J. Storage and Care of Equipment

1. Store the ceramic stirrer in an inert, dry atmosphere immediately after unloading the furnace.

2. When not in use, keep furnace tube under argon.

3. If cathode is to be used for next run, store in inert, dry atmosphere.

K. Pickle cathode in $6 \mathrm{~N} \mathrm{HCl}$ when directed to do so by supervisor.

L. Record data on data sheet (Fig. A-2). 


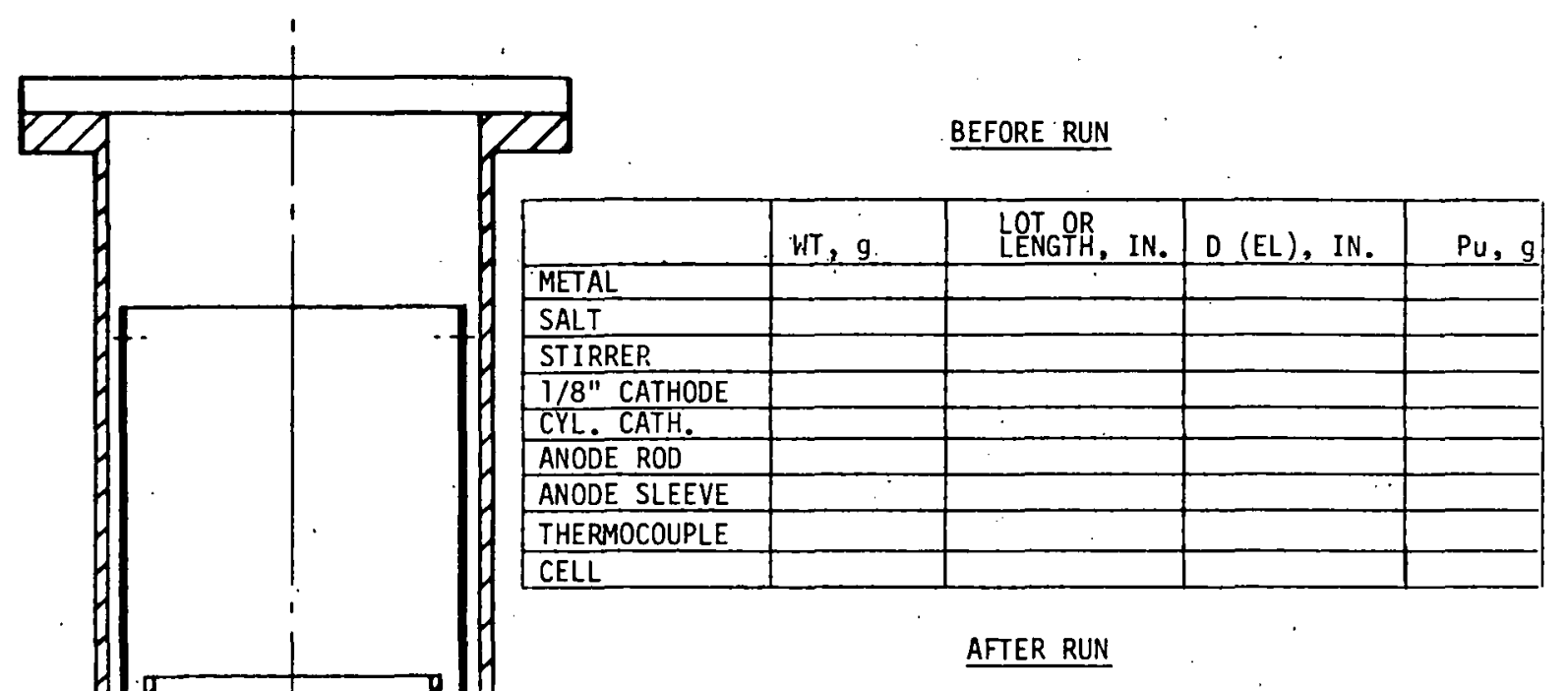

\begin{tabular}{|l|l|l|}
\hline & WI. g & Pu, g \\
\hline PRODUCT RING & & \\
\hline ANODE RES. & & \\
\hline STIRRER & & \\
\hline T/8" CATHODE & & \\
\hline CYL. CATH. & & \\
\hline ANODE ROD & & \\
\hline SALT RECOV. & & \\
\hline
\end{tabular}

\section{METER READINGS}

AMP. HR. (END OF RUN)

AMP. HR. (START OF RUN)

$g \mathrm{Pu}=$ DIFFERENCE

PU DISSOLVED

COLLECTION

DATE STARTED

DATE FINISHED 


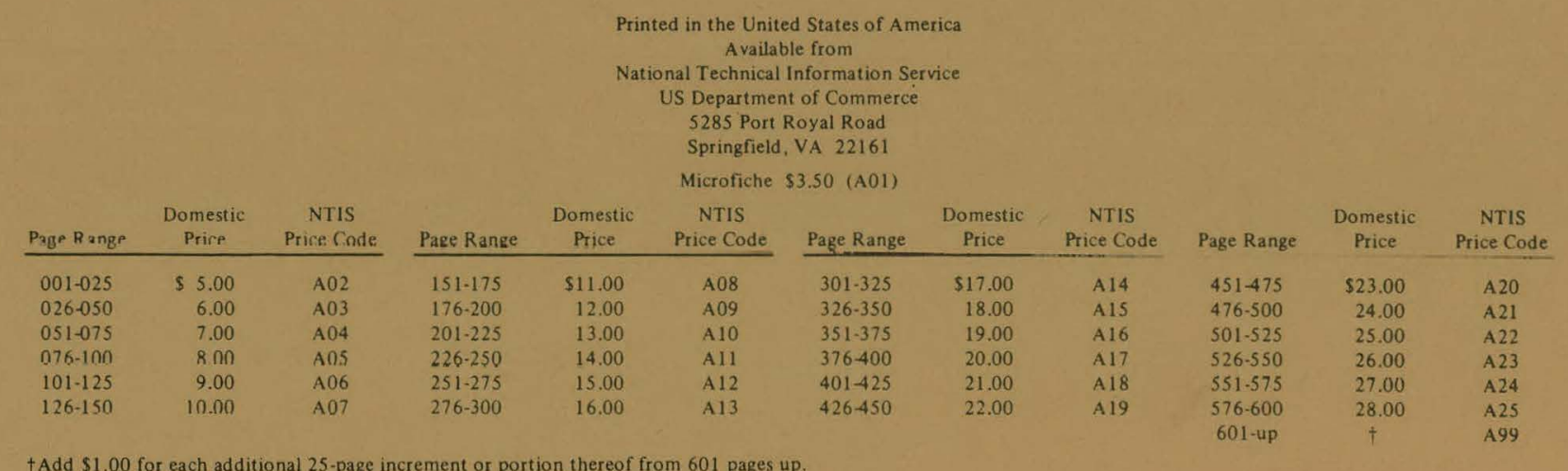

†Add $\$ 1.00$ for each additional 25-page increment or portion thereof from 601 pages up. 


\section{LOS Alannos}

